\title{
INDUKSI KALUS DAN TUNAS DARI EKSPLAN PUCUK BROKOLI (Brassica oleracea L. sub var. italica Planch) PADA MEDIUM MS YANG DIBERIKAN NAA DAN BAP
}

\author{
INDUCTION OF CALLUS AND SHOOTS OF THE EXPLANTS BUD OF BROCCOLI \\ (Brassica oleracea L. sub var. italica Planch) ON MS MEDIA WITH NAA AND BAP \\ Wenny Tilaar dan Stella Tulung*) \\ "Fakultas Pertanian Unsrat Manado
}

\begin{abstract}
The research aimed was to know the combination effect of NAA and BAP to callus and shoots induction of the explants bud of broccoli on Murashige and Skoog Medium. The research design used Completed Randomized Design in Factorial, which consisted of two treatments combination, i.e: NAA 0; 0,$1 ; 1 \mathrm{ppm}$ and BAP $0 ; 1 ; 2 ; 3 ; 4 ; 5 ; \mathrm{ppm}$. Each treatmen was repeated in three times. The observed variables were time of callus formation, time of shoot formation, high of shoot, and total shoot added to MS: Analisys of Varians. The result showed that combination of NAA and BAP influenced significantly the shoot height and the time of shoot formation however not to the total shoot of explant bud. Combination of NAA 1 ppm and BAP 3 ppm was excellent for height shoot however for the number of shoot was combination of NAA 0,1 ppm and BAP 5 ppm, and the time of shoot was on BAP 2 ppm. Callus was not formed on combination of NAA and BAP.

Keywords : broccoli, NAA and BAP, MS medium
\end{abstract}

\begin{abstract}
ABSTRAK
Tujuan penelitian ini adalah untuk mengetahui pengaruh kombinasi NAA dan BAP terhadap induksi kalus dan tunas dari eksplan pucuk brokoli yang ditumbuhkan pada media MS. Rancangan yang digunakan adalah Rancangan Faktorial dalam Rancangan Acak Lengkap terdiri dari dua kombinasi perlakuan yaitu NAA dengan konsentrasi $0 ; 0,1 ; 1$ ppm dan BAP $0 ; 1 ; ; 2 ; 3 ; 4: 5$ ppm. Setiap perlakuan diulang tiga kali. Variabel yang diamati : waktu terbentuk kalus, waktu terbentuk tunas, tinggi tunas, dan jumlah tunas. Analisis yang digunakan yaitu Analisis Ragam. Hasil penelitian menunjukan bahwa kombinasi NAA dengan BAP yang ditambahkan ke media MS, berbeda nyata pengaruhnya terhadap tinggi tunas dan waktu bertunas tetapi tidak berbeda pengaruhnya terhadap jumlah tunas dari eksplan pucuk. Kombinasi terbaik untuk tinggi tunas adalah NAA 1 ppm dengan BAP 3 ppm, sedangkan pada jumlah tunas adalah NAA 0,1 ppm dengan BAP 5 ppm, dan waktu berbertunas adalah pada BAP 2 ppm. Kalus tidak terbentuk pada kombinasi perlakuan NAA dan BAP.

Kata kunci : brokoli, NAA dan BAP, Medium MS
\end{abstract}

Eugenia Volume 19 No. 1 April 2013 


\section{PENDAHULUAN}

Kubis bunga hijau adalah tanaman yang mempunyai arti ekonomis. Seperti terlihat dalam hasil analisis usahatani bidang agroekonomi Balai Penelitian Hortikultura Lembang menemukan bahwa areal seluas 1 ha akan memperoleh keuntungan sekitar 1 juta rupiah (Sowy, 1984). Beberapa tempat di Indonesia yang sesuai untuk ditanami sayuran brokoli antara lain Pengalengan, Dieng, Tanah Karo, Lembang dan Ciloto (Sumarjono, 1980).

Kultivar yang diusahakan di Indonesia adalah kultivar introduksi yang merupakan hasil persilangan seperti kubis bunga hijau atau brokoli hibrid. Benih hibrid F1 ini tidak dapat dikembangkan ke arah produksi benih baru (Sowy, 1984).

Masalah lain adalah tanaman ini umumnya bersifat incompatibel sehingga perlu dilakukan penyerbukan silang. Benih hibrid mempunyai sifat yang kurang tegar yang menyebabkan hasil biji umumnya rendah (George and Sherrington, 1984). Salah satu jalan keluar yang akan dicoba adalah pembiakan vegetatif sistem mikropropagasi yang bermanfaat dalam mempertahankan sifat induknya, dapat mempertahankan sifat induknya dan dapat menyediakan bibit yang bermutu dalam jumlah yang banyak dengan waktu relatif singkat.

Perbanyakan secara in vitro ini, meliputi proses-proses tumbuh, difrensiasi dan perkembangan. Wareing and Phillips (1978). Mengemukakan bahwa tumbuh bersifat irreversibel. Secara kuantitatif bahwa tumbuh dapat ditentukan melalui perubahan ukuran sel, organ atau tanaman utuh.

Hess, (1975) berpendapat bahwa defenisi tumbuh bergantung pada masalah yang diformulasikan melalui pendekatan masalah. Dari segi praktis, tumbuh tertuju pada pertambahan berat kering, berat basah atau pertambahan volume sebagai fungsi waktu. Di dalam biokimia untuk parameter tumbuh diambil antara lain sintesis DNA atau protein. Bidwel (1979), mengemukakan bahwa perkembangan dapat dipengaruhi oleh hormon dan menurut Krishnamoorthy (1981), hormon ini digolongkan sebagai zat pengatur tumbuh yang disintesis dari tanaman. Saat ini banyak digunakan zat pengatur tumbuh sintetik seperti asam naftalen asetat (NAA) sebagai salah satu jenis auksin yang digunakan dalam kultur jaringan. Demikian pula bensilaminopurin (BAP) sebagai salah satu sitokinin (Zaerr and Mapes, 1982). Regenerasi tunas adventif dapat dilakukan untuk perbanyakan tanaman secara in vitro seperti yang dihasilkan pada Brassica olerasea sub sp. Green Marvel (Ravantar, Kadir, Rashid dan Haddadi, 2011).

Skoog dan Miller dalam Kamada and Harada (1979), yang pertama kali mendemonstrasikan tentang interaksi antara auksin dan sitokinin dalam medium dimana merupakan faktor penting dalam organogenesis kultur jaringan tembakau. Bila auksin lebih rendah dari sitokinin akan menginduksi tunas dan bila sebaliknya maka akan membentuk akar. Kemudian untuk menghasilkan kalus memerlukan konsentrasi yang seimbang antara auksin dan sitokinin. Martin, (2004) yang menggunakan eksplan internodul batang dari Andrographis paniculata (Burm.F.) yaitu eksplant terbentuk kalus pada kombinasi 10,74 UM NAA dengan 0,44 dan 2,22 uM BAP. Kemudian membentuk tunas pada 0,44 uM BAP.

Melalui penelitian ini akan memberikan informasi kepada para masyarakat ilmiah tentang kombinasi terbaik untuk induksi kalus dan tunas dari kubis bunga hijau secara in vitro.

Penelitian ini bertujuan untuk mengetahui pengaruh kombinasi NAA dan BAP terhadap induksi kalus dan tunas dari eksplan pucuk kubis bunga hijau secara in vitro.

\section{METODE PENELITIAN}

Penelitian ini telah dilaksanakan di laboratorium Bioteknologi Fakultas Pertanian Unsrat selama 6 bulan, sejak bulan Maret-Agustus 2010. Eksplan yang digunakan pucuk dari kubis bunga hijau (brokoli). Adapun rancangan yang digunakan adalah rancangan faktorial dalam Rancangan Acak Lengkap terdiri dari dua perlakuan kombinasi yaitu NAA (A) dengan tiga taraf konsentrasi 0 ppm(Ao); 0,1 ppm (A1) ; 1 ppm (A2) dan BAP (B) dengan 5 taraf konsentrasi 0 ppm (B0); 1 ppm (B1); 2 ppm (B2); 3 ppm (B3); 4 ppm (B4) dan 5 ppm (B5) yang masing-masing perlakuan diulang 3 kali. 
Variabel yang diamati: waktu terbentuk tunas (hari); waktu terbentuk kalus (hari); tinggi tunas $(\mathrm{cm})$ dan jumlah tunas.

Data diamati pada minggu ke delapan sesudah kultur. Data dianalisis secara analisis ragam dan dilanjutkan dengan uji BNT $5 \%$.

\section{HASIL DAN PEMBAHASAN}

\section{Tinggi Tunas}

Data pada tabel 1 menunjukan bahwa pada perlakuan tanpa NAA dan BAP tidak memberikan respon untuk pertumbuhan. Demikian pula pada beberapa ulangan seperti pada perlakuan NAA 1 ppm/BAP 1 ppm dan juga pada NAA 1 ppm/BAP 4 ppm serta pada perlakuan NAA 1 ppm/BAP 5 ppm (2 ulangan tidak tumbuh). Dengan adanya eksplan-eksplan pucuk yang tidak tumbuh ini sangat berpengaruh dalam rataan dari tinggi tunas tersebut. Rataan tinggi tunas yang tertinggi adalah pada perlakuan kombinasi NAA 2ppm/BAP $3 \mathrm{ppm}$. Dari hasil analisis ragam menunjukan bahwa pengaruh kombinasi antara NAA dan BAP terhadap tinggi tunas adalah berbeda nyata. Kemudian dilanjutkan dengan uji BNT $5 \%$.

Dari Hasil uji BNT 5\% menunjukan bahwa perlakuan kontrol atau media tanpa perlakuan berbeda nyata dengan BAP 1, 2, 3, 4, 5 ppm; NAA 0, 1 ppm; kombinasi 0, 1 ppm NAA/BAP 1, 2 ppm; dan 1 ppm NAA serta kombinasi 1 ppm NAA/BAP 2, 3 ppm. Namun tidak berbeda nyata dengan kombinasi 0,1 ppm NAA dan BAP 3 ppm serta 0,1 ppm NAA dan 4 ppm BAP. Kemudian tidak berbeda nyata dengan kombinasi 1 ppm NAA dan 4 ppm BAP serta 5 ppm BAP. Umumnya pada konsenterasi BAP yang tinggi menghambat dalam pertambahan tinggi tunas. Hal tersebut sama dengan hasil pada eksplan hipokotil brokoli yang diperoleh Tilaar, Sumeru, Bagyo, Polii-Mandang dan Tomasoa (2012); Tilaar (2012), bahwa pengaruh NAA 0 ppm yang dikombinasikan dengan 5 ppm BAP untuk tinggi tunasnya hanya mencapai $2 \mathrm{~cm}$ dibandingkan dengan tanpa perlakuan mencapai $6,5 \mathrm{~cm}$. Peran BAP sebagai zat pengatur tumbuh sitokinin hanya pembelahan sel sehingga itulah yang mengakibatkan tinggi tunasnya dibandingkan perlakuan dengan sitokinin yang rendah (Hess, 1975).

Tabel 1. Rataan Tinggi Tunas Eksplan Pucuk pada Kombinasi Perlakuan NAA dan BAP (Table 1. Average Height of Shoot from Explants Bud to Combination of NAA and BAP)

\begin{tabular}{cc}
\hline Perlakuan NAA/BAP(ppm) & Rataan Tinggi Tunas $(\mathrm{cm})$ \\
\hline AoBo & 0 \\
AoB1 & 2.233333 \\
AoB2 & 2.6 \\
AoB3 & 2.533333 \\
AoB4 & 3.333333 \\
AoB5 & 1.966667 \\
A1Bo & 1.966667 \\
A1B1 & 1.9 \\
A1B2 & 2.733333 \\
A1B3 & 1.4 \\
A1B4 & 1.466667 \\
A1B5 & 2.566667 \\
A2Bo & 5.633333 \\
A2B1 & 1.733333 \\
A2B2 & 4 \\
A2B3 & 8.766667 \\
A2B4 & 1.9 \\
A2B5 & 0.8 \\
\hline
\end{tabular}


Data Transformasi :

\begin{tabular}{ccc}
\hline Perlakuan NAA/BAP $(\mathrm{ppm})$ & Rataan tinggi tunas $(\mathrm{cm})$ & Notasi \\
\hline AoBo & 0.707107 & $\mathrm{a}$ \\
AoB1 & 1.648974 & $\mathrm{~b}$ \\
AoB2 & 1.702686 & $\mathrm{~b}$ \\
AoB3 & 1.736852 & $\mathrm{~b}$ \\
AoB4 & 1.932392 & $\mathrm{~b}$ \\
AoB5 & 1.548256 & $\mathrm{~b}$ \\
A1Bo & 1.545061 & $\mathrm{~b}$ \\
A1B1 & 1.529628 & $\mathrm{~b}$ \\
A1B2 & 1.796786 & $\mathrm{bc}$ \\
A1B3 & 1.368665 & $\mathrm{a}$ \\
A1B4 & 1.380004 & $\mathrm{a}$ \\
A1B5 & 1.733103 & $\mathrm{~b}$ \\
A2Bo & 2.45757 & $\mathrm{bc}$ \\
A2B1 & 1.393697 & $\mathrm{a}$ \\
A2B2 & 2.022517 & $\mathrm{bc}$ \\
A2B3 & 2.717795 & $\mathrm{~cd}$ \\
A2B4 & 1.451756 & $\mathrm{a}$ \\
A2B5 & 1.039051 & $\mathrm{a}$ \\
\hline BNT 5 \% & &
\end{tabular}

Keterangan : angka-angka yang diikuti huruf yang sama tidak berbeda nyata, sebaliknya angka-angka yang diikuti dengan huruf berbeda, menunjukan berbeda nyata

\section{Jumlah Tunas}

Berdasarkan hasil analisis ragam menunjukkan bahwa perlakuan kombinasi NAA dan BAP terhadap jumlah tunas dari eksplan pucuk adalah tidak berbeda nyata. Ini berarti semua perlakuan sama pengaruhnya terhadap jumlah tunas. Bila dilihat data yang ada bahwa jumlah tunas yang terinisiasi sangat sedikit bahkan umumnya eksplan hanya satu tunas saja yang terbentuk sehingga dengan demikian antara perlakuan tidak berbeda nyata. Hal ini sedikit sekali terjadinya diferensiasi tunas dari pucuk yang dikulturkan, walaupun telah diberikan BAP yang tinggi. Deferensiasi tunas yang kurang mungkin terlalu tinggi auksin internal sehingga terjadi apikal dominansi dan meristem sekunder tidak berdiferensiasi untuk tunas atau hanya sedikit yang terdiferensiasi. Auksin endogen disintesis pada bagian pucuk sehingga hanya terjadi pembelahan sel dan pemanjangan sel pada bagian ujung tunas dan pertumbuhan pucuk apical ini berlangsung terus menerus (Wareing and Phillips, 1978). Hasil ini berbeda dengan penelitian Pavlovic, et.al. (2010) mengemukakan bahwa da- lam hasilnya yaitu kultur eksplan hipokotil dengan perlakuan $1 \mathrm{mgl}^{-1} \mathrm{BA}$ dengan 0 ; 0,1 dan 0,2 $\mathrm{mgl}^{-}$ 1/BA merupakan kombinasi yang sangat baik sebab menghasilkan 3,5 sampai 7,4 tunas. Kemudian berbeda hasilnya dengan penelitian Huang, et.al. (2011) yaitu dengan penanaman hipokotil brokoli dalam kultur dengan perlakuan 0,107 uM dan 17,76 uM BAP maka menghasilkan sekitar 6,4 tunas baru. Chakraborti, Sinha dan Sinha (2006) dengan eksplan nodul stoloniferous dari $\mathrm{H}$. Cordata menghasilkan 11,00 sampai 19,40 tunas pada medium MS yang diberikan 2,22 sampai 17,74 UM BAP. Perbedaan ini mungkin adanya perbedaan jenis sehingga berbeda hasilnya.

Tabel 2 menunjukan bahwa semakin tinggi NAA dan BAP maka semakin menurun jumlah tunasnya. Hal tersebut menunjukan bahwa pada konsentrasi yang tinggi akan menghambat dalam induksi tunas. Hasil ini sama dengan penelitian Pandey, Singh, Jaiswal dan Jaiswal (2006) yaitu Induksi tunas berkurang pada kombinasi 4,44 uM BA dan 2,68 uM NAA dengan jumlah tunas hanya 3,6 saja. Sharma, Lavanya dan Anjalah (2006) yaitu 
tentang pengaruh zat pengatur tumbuh terhadap induksi tunas adventif dari eksplan pada media MS dari semua perlakuan terutama BAP. Hasilnya semakin tinggi konsentrasi BAP semakin menurun hasil induksi tunas adventif.

\section{Waktu Terbentuk Tunas}

Dalam hasil analisis ragam menunjukan bahwa perlakuan kombinasi NAA/BAP terhadap pucuk kubis bunga adalah sangat berbeda nyata pengaruhnya pada waktu terbentuknya tunas.

Tabel 2. Rataan Jumlah Tunas Eksplan Pucuk pada Kombinasi Perlakuan NAA dan BAP

(Table 2. Average Number Shoot of Bud to Combination of NAA and BAP)

\begin{tabular}{cc}
\hline Perlakuan NAA/BAP /ppm & Rataan Jumlah tunas \\
\hline AoBo & 1 \\
AoB1 & 1 \\
AoB2 & 1.333333 \\
AoB3 & 1.333333 \\
AoB4 & 1.666667 \\
AoB5 & 2.333333 \\
A1Bo & 1 \\
A1B1 & 1 \\
A1B2 & 1 \\
A1B3 & 2 \\
A1B4 & 2.666667 \\
A1B5 & 2 \\
A2Bo & 1.333333 \\
A2B1 & 1 \\
A2B2 & 1 \\
A2B3 & 1.333333 \\
A2B4 & 1 \\
A2B5 & \\
\hline
\end{tabular}

Tabel 3. Rataan Waktu terbentuk Tunas pada kombinasi Perlakuan NAA dan BAP (Table 3. Average Time Formated of Shoot to Combination of NAA and BAP)

\begin{tabular}{cc}
\hline Perlakuan & Rata-rata \\
\hline AoBo & 0 \\
AoB1 & 7.333333 \\
AoB2 & 7.666667 \\
AoB3 & 6 \\
AoB4 & 5.666667 \\
AoB5 & 7 \\
A1Bo & 6.333333 \\
A1B1 & 6.666667 \\
A1B2 & 6.666667 \\
A1B3 & 7.666667 \\
A1B4 & 7 \\
A1B5 & 6.666667 \\
A2Bo & 5.666667 \\
A2B1 & 4 \\
A2B2 & 7 \\
A2B3 & 7.666667 \\
A2B4 & 4 \\
A2B5 & 5 \\
\hline
\end{tabular}


Data Transformasi :

\begin{tabular}{ccc}
\hline Perlakuan & Rata-Rata waktu terbentuk tunas(hari) & Notasi \\
\hline AoBo & 0.707107 & $\mathrm{a}$ \\
AoB1 & 2.797567 & $\mathrm{C}$ \\
AoB2 & 2.853144 & $\mathrm{~cd}$ \\
AoB3 & 2.544443 & $\mathrm{C}$ \\
AoB4 & 2.481409 & $\mathrm{C}$ \\
AoB5 & 2.738613 & $\mathrm{C}$ \\
A1Bo & 2.603398 & $\mathrm{C}$ \\
A1B1 & 2.675578 & $\mathrm{C}$ \\
A1B2 & 2.671498 & $\mathrm{C}$ \\
A1B3 & 2.856522 & $\mathrm{~d}$ \\
A1B4 & 2.734533 & $\mathrm{C}$ \\
A1B5 & 2.671498 & $\mathrm{C}$ \\
A2Bo & 2.476343 & $\mathrm{C}$ \\
A2B1 & 1.935375 & $\mathrm{~b}$ \\
A2B2 & 2.725387 & $\mathrm{C}$ \\
A2B3 & 2.856522 & $\mathrm{~cd}$ \\
A2B4 & 1.935375 & $\mathrm{~b}$ \\
A2B5 & 2.120399 & $\mathrm{bc}$ \\
\hline
\end{tabular}

BNT $5 \%$

Keterangan : angka-angka yang diikuti dengan huruf yang sama tidak berbeda nyata, angka-angka yang diikuti dengan huruf yang berbeda, berbeda nyata

Uji BNT 5\% menunjukan bahwa kontrol atau perlakuan tanpa NAA dan BAP atau kombinasi keduanya berbeda nyata dengan perlakuan lainnya dalam pengaruhnya terhadap waktu bertunas. Namun waktu yang terbaik pada umur 5 hari sesudah kultur dengan kisaran waktu bertunas 5-9 hari. Hal ini dilihat dari respon waktu bertunas dari eksplan yang ada dalam setiap ulangan pada tabel 3. Hasil ini lebih cepat dibandingkan dengan hasil penelitian Tilaar (2009) bahwa pembentukan tunas pada perlakuan kombinasi 0 ppm NAA dan 0 ppm BAP berkisar 10 sampai 21 hari. Christey dan Earle (1991) melaporkan bahwa kisaran waktu terbentuknya tunas adventif pada Brassica oleracea dengan eksplan tangkai bunga adalah sekitar 10 hari sesudah kultur. Tilaar (2009) mengemukan bahwa waktu pembentukan tunas adventif pada eksplan hipokotil brokoli berkisar 14 sampai 20 hari. Pavlovic, et.al. (2010) melaporkan bahwa pembentukan tunas adventif dari eksplan hipokotil, kotiledon dan akar brokoli adalah 4 minggu. Sedangkan Ravantar, et.al. (2011) menyatakan bahwa untuk eksplan kotiledon dapat bertunas pada 8 minggu sesudah kultur. Jadi hal ini dapat disimpulkan bahwa waktu pembentukan tunas adventif brokoli dalam kultur ditentukan oleh eksplan yang dikulturkan.

\section{Waktu Terbentuk Kalus}

Kalus tidak terbentuk pada seluruh perlakuan kombinasi NAA dan BAP. Pada pangkal pucuk tidak terjadi inisiasi kalus sampai selesai penelitian. Hal tersebut mungkin konsentrasi yang diberikan pada kombinasi perlakuan ini tidak sesuai untuk terbentuk kalus atau mungkin pelukaan tidak dilakukan pada eksplan tersebut sehingga peluang untuk terjadi kalus sangat kecil sekali.

\section{KESIMPULAN}

Kombinasi NAA dengan BAP yang ditambahkan ke media MS, berbeda nyata pengaruhnya terhadap tinggi tunas dan waktu bertunas tetapi tidak berbeda pengaruhnya terhadap jumlah tunas dari eksplan pucuk.

Kombinasi terbaik untuk tinggi tunas adalah NAA 1 ppm dengan BAP 3 ppm, sedangkan pada jumlah tunas adalah NAA 0,1 ppm dengan BAP 5 ppm, dan waktu bertunas adalah pada BAP 2 ppm. Kalus tidak terbentuk pada kombinasi perlakuan NAA dan BAP. 


\section{DAFTAR PUSTAKA}

Bidwell, R. G. S. 1979. Plant Physiology. $2^{\text {nd }}$ ed. Macmillan Publishing Co. New York. hal : 89-145.

Chakraborti, S., S. Sinha and R. K Sinha 2006. High Frequensi induction of Multiple shoot and Clonal Propagation from Rhizomatous Nodul Segments Of Houttunia Cordata Thunb.-An Etnomedicinal Herb of India. In Vitro Cell Dev. Biol. Plant 42: 394-398 2006.

George, E. F. and P. D. Sherrington. 1984. Plant Propagation by Tissue Culture. Handbook and Directory of Comercial Laboratories. Exegetics Limited., England hal. 184-244.

Hess, D. 1975. Plant Physiology. Toppan Company Pte. Ltd. New York, Singapore.

Huang K, Q. Wu, J.Lin, and J. Zheng. 2011. Optimization of Explant Regeneration Protocol for Broccoli. African Journal of Biotechnology Vol. 10(20) : 4081-4085.

Kamada, H. and H. Harada. 1979. Influence of Several Growth Regulators and Amino Acid In vitro Organogensesis of Torenia fournieri. Lind. J. Exper. Bot. 30(114) : 2736.

Krishnamoorthy, H. N. 1981. Plant Growth Substances. McGraw Hill Publishing. New Delhi. hal : 1-48.

Martin K.P 2004. Plant Regeneration Protocol of Medicinaly Important Andrographis paniculata (Burm.F.) Wallich Ex Nees Via Somatic Embriogenesis. In Vitro Cell. Dev. Biol. Plant 40.204-209. March-April 2004.

Pandey S, M.Singh, U. Jaiswal and V. S Jaiswal. 2006. Shoot Initiation and Multiplication from a. Mature Tree Of Terminalia arjuna Roxb. In Vitro Cell Dev.Biol.- Plant 46: 165-1732006.

Pavlovic S, B. Vinterhalter, N. Mititc, S. Adzic, N. Pavlovic, M. Zdravkovic and D. Vinterhalter. 2010. In Vitro Shoot Regeneration from seedling explants in
Brassica Vegetables: Red Cabbage, Broccoli, Savoy Cabbage and Cauliflower. Arc.Biol SCi. Belgrade, 62(2) : 337-324.

Ravantar S.A., M.A Aziz, M.A Kadir, A.A Rashid, and F. Haddadi. 2011. In Vitro Adventitious Shoot Regeneration and acclimatization of Brassica olerasea subsp.italica cv Green Marvel. African Journal of Biotechnology. 10(29):56145619.

Sowy, M. A. 1984. Penelitian dan Pengembangan Kubis Bunga di Balai Penelitian Hortikultura Lembang. Fakultas Pertanian, IPB. Bogor.

Sunarjono, H. 1980. Budi Daya Kubis PT Soeroengan Jakarta.

Sharma K. K, M. Lavanya and V. Anjalah. 2006. Agrobacterium-Mediated production of Transgenic Pigeonpea (Cajanus cajan $L$. Millssp) Expressing the Synthetic BT CRYAB Gene. In Vitro Cell Dev.Biol.Plant 46: 165-173 2006.

Tilaar, W., Sumeru Ashari, Bagyo Yanuwiadi, Jeany Polii-Mandang, and Francien $\mathrm{H}$. Tomasowa. 2012. Shoot Induction from Broccoli Explant Hypocotyls and Biosynthesis of Sulforaphane. IJBAS: International Journal of Basic \& Applied Sciences Vol: 12 Issue: 06 p. 44-48.

Tilaar, W. 2012. Mikropropagasi Brokoli (Brassica oleracea L.var. Italica Plench) dan Peningkatan Sulforafan Selama Pembentukan Plantlet. Disertasi S3 Fak.Pertanian UB Malang.

Wareing, P. F. and I. D. J. Phillips 1978. The Control of Growth and Differentiation in Plants. $2^{\text {nd }}$ ed. Pergamon Press. Oxford, New York. Toronto. Sydney. Paris. Frankfurt.

Zaer, J. B. and M. O. Mapes 1982. Action of Growth regulators. In : Tissue Culture in Forestry. Martinus Nijhoff Publishers, Dodrecht, The Nederlands. 
